\title{
Hatay yellow strain (Bombyx mori L.) under the threat of extinction: Determination of morphological and biological features with some reviews
}

İpekböcekçiliğinde yok olma tehditi altında olan Hatay sarısı ırkı (Bombyx mori L.): Bazı incelemelerle morfolojik ve biyolojik özelliklerinin belirlenmesi

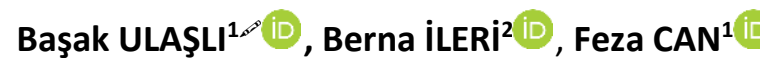 \\ ${ }^{1}$ Hatay Mustafa Kemal University, Faculty of Agriculture, Department of Plant Protect, Antakya-Hatay, Turkey. \\ ${ }^{2}$ Canakkale Onsekiz Mart University, Faculty of Fine Arts, Department of Textile and Fashion Design, Çanakkale, Turkey.
}

\section{MAKALE BILGISI / ARTICLE INFO}

\section{Makale tarihçesi / Article history:}

DOI: $10.37908 /$ mkutbd.860085

Geliş tarihi /Received:13.01.2021

Kabul tarihi/Accepted:04.03.2021

Keywords: Bombyx mori, Hatay yellow strain, peace silk, biology, Turkey.

\footnotetext{
Corresponding author: Başak ULAŞL

$\bowtie:$ btok@mku.edu.tr
}

\section{ÖZET / A B STR A C T}

Atıf / Citation: Ulaşlı B, ileri B, Can F (2021) Hatay yellow strain (Bombyx mori L.) under the threat of extinction: Determination of morphological and biological features with some reviews. MKU. Tar. Bil. Derg. 26(2) : 266-271. DOI: 10.37908/mkutbd.860085

\section{INTRODUCTION}

Although sericulture in Hatay dates back to the Byzantine Period, it is one of the most important silk weaving centers in the Ottoman Period. It is seen that silkworm breeding and weaving was intensive in the region until the 1900s. In some villages in iskenderun, Antakya and Samandağ districts, especially Hıdırbey, 
Kebusiye, Vakıflı, Batıayaz, Yoğunoluk and Eriklikuyu villages, silkworm cultivation and weaving has been a common occupation, and it is famous with that the local villagers produce raw silk and produce silk handkerchiefs and scarves on hand looms. After Hatay was joined to the Rebuplic of Turkey (1939), sericulture started to revive again (ileri, 2019). Today, silkworm cultivation is carried out by approximately 30 families in Samandağ and Defne districts of Hatay with the hybrid breed that knits a white cocoon distributed by KOZABIRLiK every year.

Among lepidopteran insects, silkmoths are the most studied ones. Silkmoths, are divided into two main groups as those fed mulberry (Lepidoptera: Bombycidae) and non-mulberry (Lepidoptera: Saturniidae, Lasiocampidae) plants. The silkworm, Bombyx mori (Linnaeus, 1758) (Lepidoptera: Bombycidae), is one of the best characterized insect in the order Lepidoptera, is in the mulberry-fed group and is the only domesticated insect that depends only on humans to survive (Banno et al., 2004; Arunkumar et al., 2006; Lenin, 2015). The firststage larvae that hatch from silkworm eggs are black, and later stage larvae are white and this period lasts approximately $25-28$ days. The weight of the last-stage larvae, the $5^{\text {th }}$ instar, increases approximately 10,000 times compared to that of the first-stage larvae, and towards the end of this period, the larva begins to look for a place to spawn a cocoon. While spawning the cocoon, the larva makes movements similar to the figure 8 with head movements and completes the cocoon in 23 days. It secretes $1200-1600 \mathrm{~m}$ of silk fiber to weave a cocoon (Özkavruk Adanır, 2015). The silkworm B. mori is one of the most well characterized silk-producing organisms. Silkworm has a pair of silk glands and these glands, which were very small in the first larval stages, grow very large towards the end of the $5^{\text {th }}$ instar. Silk glands consist of three parts, each playing different roles in silk secretion. The lower part known as the posterior, secretes the silk substance known as "fibroin". The middle part, known as the median, acts as a reservoir for the fibron and secretes the adhesive substance called "sericin". The anterior part, on the other hand, is a channel that allows the fibron and the sericin to become fiber (Hou et al., 2007; Şahan, 2011; Abdelli et al., 2018). The composition of the silk contains fiber protein fibroin, serizine known as soluble silk gum (Şahan, 2011), as well as various protease inhibitors, enzymes, unknown function proteins and other proteins. Silk proteins are stored in the lumen of the silk gland for about 8 days in the $5^{\text {th }}$ instar. Some of the identified silk proteins have specific roles in silk. For example, protease inhibitors can prevent the thread from spoiling (Dong et al., 2016).
However, it is very important in the production of silk fiber, animal protein, bioreactor, it also plays a role as an important research model within the Lepidoptera (Chen et al., 2019).

Silkworm eggs have been produced by using polyhybrid M-China, N-Japanese parent lines in Koza Agricultural Sales Cooperatives Union (KOZABIRLIK) located in Bursa in Turkey. Eggs are distributed free of charge to producers who want to breed silkworms under the supervision of KOZABIRLiK. According to Şahan (2011), after 1974, the local race/domestic strain of Hatay yellow strain was replaced by this hybrid breed, which completely weaves a white cocoon. Being faced with the danger of extinction the Hatay yellow, is Turkey's remarkable native silkworm race with the cocoon which it spins in many different shades of colours from cream to yellow, even orange.

Around the world, "Environmental Organizations and Animal Rights Advocates" defends the continuation of the silkworm's natural life cycle and they react to the 'strangling process' which kills the silkworm in ovens as a moth inside the cocoon. This foundations advocate transforming the cocoon into yarn after the moth emerges from the cocoon. Many consumers, who want to use silk products abroad, especially want that "none of the silkworms getting killed or being exposed to violence" for the silk they buy. Based on Mahatma Gandhi's ahimsa philosophy (not hurting any living thing, respecting the soul of every living thing) in India, Ahimsa silk production started about 20 years ago. In a very short time, silk has been adopted as sustainable / ecological / vegan / organic textiles in Europe, and a large purchaser mass has been created in many countries with names such as peace silk / non violence silk (Sannapapampa and Shailaja, 2014; Plannthin, 2016; Sharma, et. al., 2016; Anonymous, 2020).

As a result of research conducted in Turkey the peace silk / silk peace / non-violent silk production in the form of "silk" is unknown to producers and consumers, hence, it was determined that this kind of silk is not used for domestic silk market. Thus, Turkey's peace silk production has begun only to contain the producers in Hatay. For the first time in Turkey, with a scientific approach and under observation, silkworm was bred having moths allowed to leave their cocoons and complete their normal life cycle. Therefore, in peace silk production an alternative production method was created for breeders and the industry (ileri et al., 2020). Considering the issues explained and emphasized above, it was thought that the morphological and some biological characteristics of the Hatay yellow, which is a native strain specific to our country, should be brought 
back to silk production after half a century and there has been a need to update the old information. Already prepared by the Food, Agriculture and Livestock Ministry "Turkey Animal Genetic Resources National Strategy and Action Plan (2015-2020)" 's strategic priority described

\section{MATERIALS and METHODS}

\section{Breeding the Hatay yellow strain}

After 8 years of exploration work, the yellow cocoons were found in June 2019 and than adults emerged from the cocoons and eggs were obtained. It started with these eggs to be hatched from March-April 2020, and the breeding of Hatay yellow strain continued in Harbiye district of Hatay Province until the end of July 2020. The larvae that emerged from the eggs were fed with mulberry leaves until the cocoon stage. The feeding of the 1000 larvae and their molting stages were observed as "Animal Genetic Resources Characterization (GCM)" under the heading morphology of the animal race, the identification of physiological and genetic characteristics and the necessity of "updating" the knowledge is emphasized (Anonymous, 2015b).

and, regular cleaning were made for their healthy development. After the larvae became the 5 th instar, for many years, as the oldest growers did, Spanis broom, Spartium junceum (Fabaceae) plants were brought from the nature and placed on the production benches and the larvae were allowed to weave cocoons between the thin branches of this plant. After the cocoon knitting process is completed, the cocoon has been harvested and awaited for the moth emergence. Thus, in accordance with the peace silk production method, the mating and egg laying process of the silk worm emerging from the cocoons in accordance with their natural cycles without choking started.

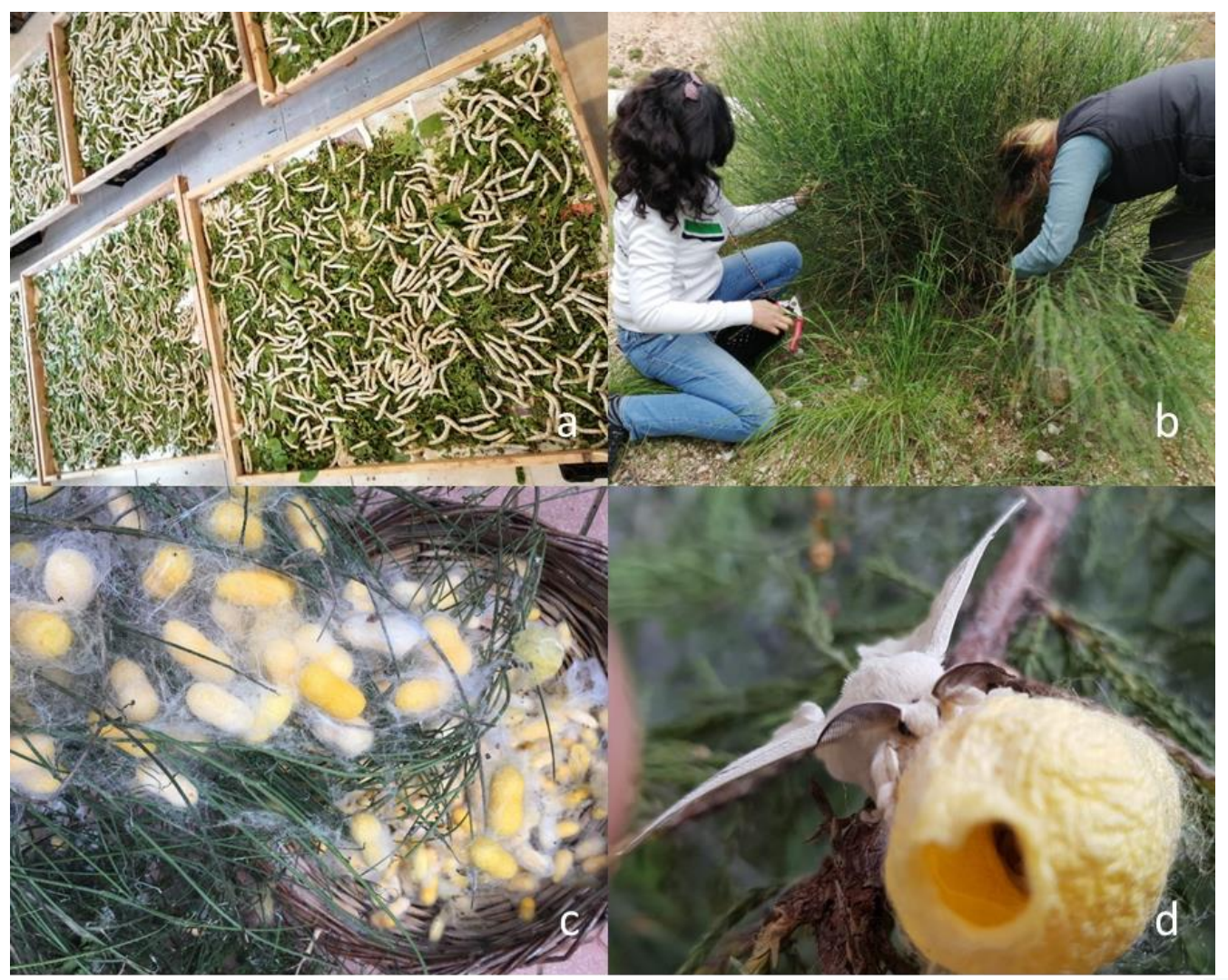

Figure 1. A) Feeding process of Hatay yellow strains' larvae B) collecting the Spanis broom plants C) cocoon knitting process $D$ ) the production of adult according to the "peace silk" method

\section{Determination of the morphological and biological characteristics of the Hatay yellow strain}

The development of the first-stage larvae hatching from the eggs that are cultured in the natural habitat under the climate-appropriate lighting time, temperature and humidity conditions in the spring; The period of five larvae stages, called an instar separated by four molting, cocoon period and moth emergence from the cocoons were observed, examined and photographed in detail under the microscope. The cocoon knitting stage was also recorded with videos and photographs, and the colour scale of the cocoons was created. This process was applied for both generations of Hatay yellow. After moths died, their wings were spreaded and labeled and 


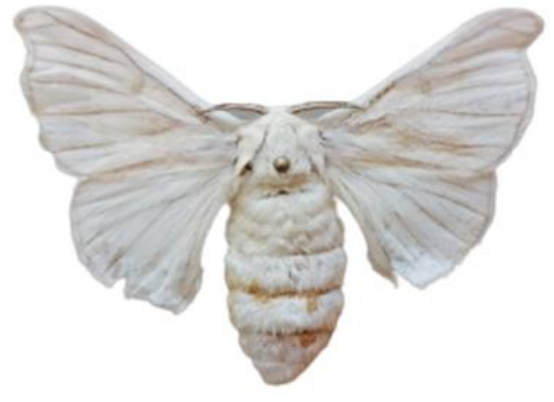

a

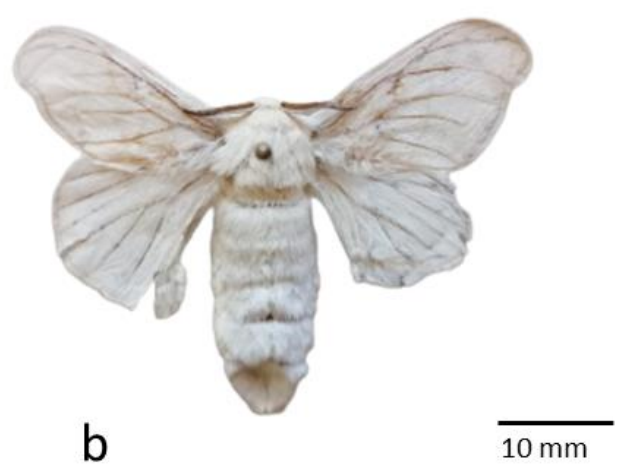

b

Figure 2. Hatay yellow strains' A) female B) male

prepared as museum material (Doğanlar, 2003) (Figure $2 a, b)$.

\section{RESULTS and DISCUSSION}

The development periods from egg to adult stage of Hatay yellow cultured in their natural habitat were followed. Due to the poor flying characteristics of silk moths, the biological development of numerous silk moths was easily monitored and it was observed that they mated and laid eggs in a healthy manner.

This study was conducted in it's natural habitat in Harbiye district of Hatay province in March-July 2020. The first-stage larvae emerging from the eggs of Hatay yellow took place in the second week of March and continued until April. It was observed that the larvae had 5 stages by molting 4 times and larval period varied according to the first and second generation with approximately 45 and 38 days, respectively. However, it has been reported in various studies that this period is an average of one month in different silkworms (Akkır, 2010; Şahan, 2011; Özkavruk Adanır, 2015).

In all the literature about Hatay yellow, it is stated that the moth gives one generation in a year, (Şahan, 2011; Anonymous 2015a; Anonymous, 2015b) but in this study, the larvae of the second generation emerged from the eggs under natural conditions and their healthy development continued and completed their life cycle (Figure 3a). It was easy to observe this period since the larvae, which were black and very small in the first instar period, were known to be white in the second instar period (Anonymous 2015a) (Figure 3b). The morphological characteristics of the silkworm, especially the $5^{\text {th }}$ instar, is the late stage larvae, are very important. The yellow colour of the abdomen legs in this stage is an important distinguishing feature of the Hatay yellow (Figure 3c). In addition, the "mark" in the second segment of the abdomen is almost like a parenthesis sign, and the "star point" in the $5^{\text {th }}$ segment becomes the most visible in this period (Figure $3 \mathrm{~d}$ ). For this reason, all the morphological features of the last larval stage were examined in detail under the microscope. According to Anonymous (2015a), the cocoons of Hatay yellow are stated to be in the colour of the pale orange. But it is determined in this study that its cocoon has about 20 different shades of colour from cream to light yellow to very dark yellow even orange.

In the first generation of Hatay yellow, each period of the first three larval stages lasted approximately 4-6 days, while the fourth and fifth larval stages were longer than the first three stages, lasting approximately one month. In addition, it has been observed that the fifth-stage larvae knit the cocoons in 3-5 days, the adult emerge from the cocoon is completed in 3-4 weeks and after the mating egg laying period of the adults takes 0-3 days. Some of the eggs from this offspring were stored for the next year, some were kept in their natural environment to obtain the second generation, and observation continued. The eggs of the first generation matured and started to hatching after about two weeks. Therefore, it was seen that first stage larvae emerged from the eggs in the second generation in the first days of June. The last stage larvae started to knit cocoons in the first week of July, thus the larval period ended. In the last week of July, adults emerged from the cocoons and the adults of the second generation mated and laid eggs, and the eggs were stored under natural conditions for the next year. As a result of the observations in the study, the life cycles of Hatay yellow strain were completed in 70 days in the first generation and 55 days in the second generation. The main reason for this difference is thought to be due to the fact that the air temperature in our country in March 2020, and therefore in Hatay-Harbiye, is quite cool compared to seasonal norms. This period is a critical period when the leaves on mulberry trees have just begun to bud breaking due to cold weather and at the 
same time the first feeding of the newly hatched larvae of the monophagous Hatay yellow will contribute to survive. As a result, it is thought that this difference in the completion of generation is caused by both temperature stress and food stress. The examine/study their life cycle and the stages under pre-determined laboratory conditions is a new area/subject that needs to be investigated.

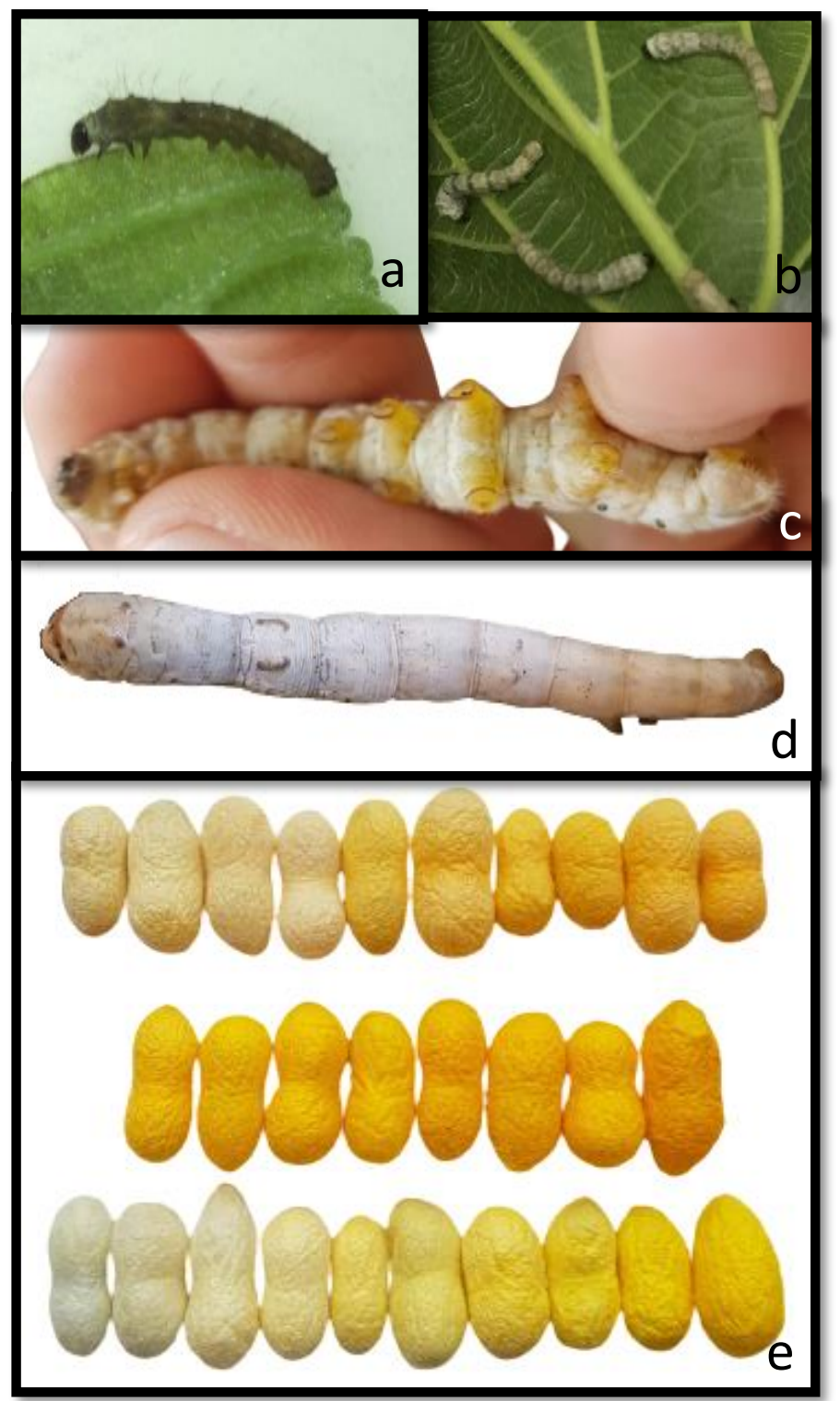

Figure 3. Hatay yellow strains' A) first-stage larvae, B) second-stage larvae, (C,D) fifth/last-stage larvae, E) different colour coccons

In conclusions, in the light of the data obtained, the biological characteristics of moths such as the life cycle, the development period of the periods and the number of offspring per year, as well as the new morphological characteristics of the adult and pre-mature periods were determined, and those previously known were also updated.

With the results of this study both silkworm native strain Hatay yellow, which is the cultural heritage of our country and under the danger of extinction for nearly half a century, can be raised again and will be provided sustainability with the production of silk by using world preferred "peace silk" method. Also the first steps have been taken to the sustainability of scientific knowledge in Turkey.

\section{ÖZET}

Amaç: İpek lifi tarih boyunca önemini koruyan, günümüzde katma değeri yüksek tekstil ürünlerinin vazgeçilmez liflerinden birisidir. Yaklaşık 5000 yıl önce evcilleştirilmiş bir böcek olan ipek böceğinin yerli ırkı, Hatay sarısına sahip olması ülkemizin önemli ayrıcalıklarından birisidir. Ülkemizde uzun yıllardır sadece beyaz koza ören hibrit ırkın yetiştirildiği ipekböcekçiliğinde, Hatay'ın yerel ırkı olan Hatay sarısının üretimi neredeyse son 45 yıldır yapılmamaktadır. Yok olma tehlikesi ile karşı karşıya olan bu yerli ipekböceği ırkının bazı morfolojik ve biyolojik özelliklerinin araştırılması hedeflenmiştir.

Yöntem ve Bulgular: Hatay ilinin Harbiye ilçesinde 2020 yılında, iklime uygun ışıklanma süresi, sıcaklık ve nem koşullarında doğal yaşam alanında kültüre alınan yumurtalardan mart ayında ilk dönem larvaların çıkmasıyla beraber 1000 larvanın gelişimleri; dört kez gömlek değiştiren beş larva dönemi, koza dönemi ve kozalardan kelebek çıkış süreci takip edilmiştir. Bu işlem her iki döl için de uygulanmıştır. Kelebekler öldükten sonra kanatları gerilerek etiketlenmiş, müze materyali olarak hazırlanmıştır.

Genel Yorum: Bu çalışma sonucunda Hatay sarısı ırkı yeniden yetiştirilebilmiş, doğaya kazandırılarak, hem dünyada ipek üretiminde tercih edilen "barış ipeği" yöntemi ile üretimine imkan sağlanmış hem de Türkiye'de bilimsel bilgiler ışığında sürdürülebilirliği için ilk adımlar atılmıştır.

Çalışmanın Önemi ve Etkisi: Ülkemizin yerli ipekböceği ırkı Hatay sarısının doğal yaşam ortamı olan Hatay'da iki döl verdiği ilk kez bu çalışma ile belirlenmiş ve biyoekolojik özelliklerine önemli bir katkı sunulmuştur. Böylece kelebeklerin hayat döngüsü, dönemlerin gelişme süreleri ve yılda verdiği döl sayısı gibi biyolojik özellikleri, ayrıca ergin ve ergin öncesi dönemlerinin yeni morfolojik özellikleri belirlenmiş, daha önce bilinenler de güncellenmiştir. 
Anahtar Kelimeler: Bombyx mori, Hatay sarısı ırkı, barış ipeği, biyoloji, Türkiye

\section{ACKNOWLEDGEMENTS}

We would like to thank Mrs. Emel Duman and Mr. Fikret Duman, who provided the opportunity to breed silkworms in their personal production facilities in Harbiye district of Hatay province for their great support and also to "Hatay Mustafa Kemal University Establishment and Sustention Foundation" for their contributions.

\section{CONFLICT OF INTEREST}

The authors declare no conflict of interest for this study.

\section{AUTHOR'S CONTRIBUTIONS}

The contribution of the authors is equal.

\section{REFERENCES}

Abdelli N, Peng L, Keping C (2018) Silkworm, Bombyx mori, as an alternative model organism in toxicological research. ESPR 25: 35048-35054.

Akkır ED (2010) Üç yerli ipekböceği ırkının (Alaca, Bursa Beyazi ve Hatay Sarisi) bazı moleküler genetik ve morfolojik özelliklerinin araştırılması. Doktora Tezi, Kırıkkale Üniversitesi, Fen Bil. Ens., Biyoloji ABD, $121 \mathrm{~s}$.

Anonymous (2015a) Gıda, Tarım ve Hayvancilık Bakanlı̆̆ı, Hayvan Genetik Kaynakları Araştırmaları ve Yönetim Faaliyetleri, TAGEM, Ankara, $55 \mathrm{~s}$.

Anonymous (2015b) Gıda, Tarım ve Hayvancılık Bakanlı̆̆ı, Türkiye Hayvan Genetik Kaynakları Ulusal Strateji ve Eylem Planı (2015-2020), TAGEM, Ankara, $93 \mathrm{~s}$.

Anonymous (2020) People for the Ethical Treatent for Animals. Retrived December 22, 2020, from https://www.peta.org/

Arunkumar KP, Metta M, Nagaraju J (2006) Molecular phylogeny of silkmoths reveals the origin of domesticated silkmoth, Bombyx mori from Chinese Bombyx mandarina and paternal inheritance of Antheraea proylei mitochondrial DNA. Mol. Phylogenet. Evol. 40(2): 419-427.

Banno Y, Nakamura T., Nagashima E, Fujii H, Doira H (2004) M chromosome of the wild silkworm, Bombyx mandarina (n D27), corresponds to two chromosomes in the domesticated silkworm, Bombyx mori (nD 28). Genome 47: 96-101.

Chen DB, Zhang RS, Bian HX, Li Q, Xia RX, Li YP, Liu YQ, Lu C (2019) Comparative mitochondrial genomes provide new insights into the true wild progenitor and origin of domestic silkworm Bombyx mori. International Int. J. Biol. Macromol. 131: 176-183.

Doğanlar F (2003) Doğu Akdeniz Bölgesinde Geometidae (Lepidoptera) familyası üzerinde faunastik ve sistematik araştırmalar. Doktora Tezi, Çukurova Üniversitesi, Fen Bilimleri Enstitüsü, Bitki Koruma ABD, $295 \mathrm{~s}$.

Dong $Z$, Zhao $P$, Zhang $Y$, Song $Q$, Zhang $X$, Guo $P$, Wang $D$, Xia $Q$ (2016) Analysis of proteome dynamics inside the silk gland lumen of Bombyx mori. PubMed Scientific Reports 22(6): 21158.

Hou Y, Xia Q, Zhao P, Zou Y, Liu H, Guan J, Gong J, Xiang $Z$ (2007) Studies on middle and posterior silk glands of silkworm (Bombyx mori) using twodimensional electrophoresis and mass spectrometry. Insect Biochem. Mol. Biol. 37: 486496.

Ileri B (2019) Hatay'da İpeğin Tarihi, Hatay Araştırmaları IV, Kültür Bakanlığı Yayınları, Ankara, 85-96.

Ileri B, Özkavruk Adanır E, Can F, Ulaşlı BT (2020) Tekstil tasarımda yeni bir yaklaşım: Kelebeğe zarar vermeden ipek giymek. $5^{\text {th }}$ International Scientific Research E-Congress (IBAD), September 01-02, Istanbul, Turkey, p 6.

Lenin EA (2015) Generic and evolutionary view on domestic and wild silkworms through cytochrome oxidase subunit I genes. J. Entomol. Zool. Stud. 3(4): 267-271.

Özkavruk Adanır E (2015) Tekstil Lifleri Mungan Kavram Yayınevi, İzmir, $281 \mathrm{p}$.

Plannthin DK. (2016) Animal Ethics and Welfare in the Fashion and Lifestyle Industries. In: Green Fashion (Eds. Muthu S., Gardetti M), Environmental Footprints and Eco-design of Products and Processes. Springer, Singapore, pp 49-122.

Sannapapampa KJ, Shailaja DN (2014) Ahimsa silk union fabrics-A novel enterprise for handloom sector. Indian J. Tradit. Knowl. 14(1): 488-492.

Sharma N, Minakshi J, Kashyap R (2016) Assessment of physical properties of cotton with Ahimsa and conventional silk union fabrics. IJSR 7(4) 458-462.

Şahan Ü (2011) Ipekböceği yetiştirme ve ıslahı, koza üretimi, ham, ipek, yumurta üretimi, hastalıklar ve dut yetiştirme. Dora yayınları, Bursa, 150. 